\title{
Targeting few to help hundreds: JAK, MAPK and ROCK pathways as druggable targets in atypical chronic myeloid leukemia
}

\author{
Stefania Rocca', Giovanna Carrà ${ }^{1}$, Pietro Poggio ${ }^{1}$, Alessandro Morotti ${ }^{2}$ and Mara Brancaccio ${ }^{1 *}$ (D)
}

\begin{abstract}
Atypical Chronic Myeloid Leukemia (aCML) is a myeloproliferative neoplasm characterized by neutrophilic leukocytosis and dysgranulopoiesis. From a genetic point of view, aCML shows a heterogeneous mutational landscape with mutations affecting signal transduction proteins but also broad genetic modifiers and chromatin remodelers, making difficult to understand the molecular mechanisms causing the onset of the disease. The JAK-STAT, MAPK and ROCK pathways are known to be responsible for myeloproliferation in physiological conditions and to be aberrantly activated in myeloproliferative diseases. Furthermore, experimental evidences suggest the efficacy of inhibitors targeting these pathways in repressing myeloproliferation, opening the way to deep clinical investigations. However, the activation status of these pathways is rarely analyzed when genetic mutations do not occur in a component of the signaling cascade. Given that mutations in functionally unrelated genes give rise to the same pathology, it is tempting to speculate that alteration in the few signaling pathways mentioned above might be a common feature of pathological myeloproliferation. If so, targeted therapy would be an option to be considered for aCML patients.
\end{abstract}

Keywords: Atypical myeloid leukemia, Ruxolitinib, Trametinib, Fasudil, MAPK, ROCK, JAK2, CSF3R

\section{Background}

Atypical Chronic Myeloid Leukemia (aCML) is an aggressive and genetically heterogeneous disease for which no standard of care exists. The classification of aCML, which is included in the group of Philadelphia-negative myeloid neoplasms, has been a matter of debate for years. While the identification of the translocation $\mathrm{t}(9 ; 22)(\mathrm{q} 34 ; \mathrm{q} 11)$ in a patient with accumulation of mature granulocytes and their precursors is sufficient for the diagnosis of Chronic Myeloid Leukemia (CML) [1, 2], the absence of this translocation is pathognomonic of Philadelphia-negative Myeloproliferative Neoplasms. Given the concomitant presence of myeloproliferation and myelodysplasia, the 2002 World Health Organization (WHO) classification of myeloid neoplasms places aCML under the category called myelodysplastic/myeloproliferative neoplasms (MDS/MPN) [3] and the 2008 and 2016 revisions of WHO criteria did not change the classification $[4,5]$. The MDS/MPN group includes chronic myelomonocytic

\footnotetext{
* Correspondence: mara.brancaccio@unito.it

${ }^{1}$ Department of Molecular Biotechnology and Health Sciences, University of

Torino, 10126 Torino, Italy

Full list of author information is available at the end of the article
}

leukemia (CMML), aCML, juvenile myelomonocytic leukemia (JMML), MDS/MPN with ring sideroblasts and thrombocytosis and MDS/MPN unclassifiable (MDS/ MPN-U). According to the $2008 \mathrm{WHO}$ classification of myeloid neoplasms and acute leukemia, the absence of $B C R-A B L$ and PDGFRA, PDGFRB or FGFR1 rearrangements are minimal diagnostic criteria for aCML $[4,6]$. However, the main feature characterizing aCML is the presence of neutrophilic leukocytosis and marked dysgranulopoiesis. Moreover, to fulfil the diagnostic criteria, the white blood count (WBC) should be $\geq 13 \times 10^{9} / \mathrm{L}$ with $\geq 10 \%$ of immature granulocytes and $\leq 20 \%$ blasts in the blood and the bone marrow $[4,6]$. These diagnostic guidelines have been then applied in different studies that analyzed histopathological features and clinical data available for similar types of myeloid neoplasia like Chronic Neutrophilic Leukemia (CNL) and MDS/MPN-U. These reports confirmed that $\mathrm{WHO}$ criteria were really suitable to distinguish aCML from similar diseases [7-11]. For what concern patients' treatment, no standard of care exists. Hematopoietic stem cell (HSC) transplantation is always the best option when a matching donor is available. Without this possibility, patients can be considered for 
treatment with general drugs like hypomethylating agents, pegylated-interferon- $\alpha$, hydroxyurea, and/or erythropoiesis stimulating agents or for enrollment in clinical trials with specific inhibitors (the case of ruxolitinib and trametinib will be discussed later in this review) [12]. However, patients' survival, which has been analyzed in different studies with some differences, remains dismal. In an Italian cohort of $55 \mathrm{aCML}$ cases respecting the WHO criteria, the median overall survival was 25 months [13], while in an US study of 65 patients it was found to be 12.4 months [11].

\section{Recurrent signaling pathways involved in myeloproliferation}

A big effort has been made in the last decades to elucidate the molecular mechanisms leading to myeloproliferation. The identification of oncogenic mutations in signal transduction proteins pointed to the role of specific pathways in inducing excessive proliferation of myeloid lineages [14]. The subsequent development of mouse models carrying mutations found in patients and, conversely, the analysis of unexpected myeloproliferative phenotypes in genetically modified mice proved that the aberrant activation of these specific pathways plays a causal role in the onset of the pathology [15]. It came out that pathological myeloid proliferation is supported by few signaling pathways known to induce myelopoiesis by transducing signals from cytokines and growth factor receptors [16-19]. In this review we will primarily focus on three signal transduction pathways, the Janus kinase 2/signal transducers and activators of transcription (JAK2/STAT), the mitogen-activated protein kinase (MAPK) and the Rho associated coiled-coil containing protein kinase 1/2 (ROCK1/2) pathways. For all of them a role in myeloproliferation has been demonstrated by in vitro and in vivo studies and their involvement in human myeloproliferative diseases, including aCML, has been described $[6,14,20,21]$. Moreover, inhibitors targeting signal transduction components of these pathways are already in clinical use and have the potential to be used for personalized treatment of aCML patients.

\section{The JAK2/STAT pathway}

JAK2 is a tyrosine kinase that plays an essential role in myelopoiesis by transducing cytokine signals from several receptors, like receptors for erythropoietin (EPO-R), thrombopoietin (TPO-R) and granulocyte colony-stimulating factor (G-CSF-R). JAKs associate with cytoplasmic domains of different cytokine and growth factor receptors. The binding of extracellular ligands causes changes in the receptors that permit the associated intracellular JAKs to phosphorylate one another. Trans-phosphorylated JAKs then phosphorylate downstream substrates, including STATs. Activated STATs enter the nucleus and bind to specific enhancer sequences in target genes, thus regulating their transcription [22].

The mutation that causes the substitution V617F results in the activation of JAK2 signaling even without receptor stimulation, leading to ligand-independent granulocyte proliferation [20]. The JAK2 V617F mutation is found rarely in aCML cases [23, 24], while it is frequent in Polycythaemia Vera (PV), Essential Thrombocythemia (ET) and Myelofibrosis (MF) [5]. Although infrequent, JAK2 V617F mutated cases could benefit of the JAK2 inhibitor ruxolitinib, already in clinical use for the treatment of intermediate or high-risk MF $[24,25]$. There are no standard treatment options for MF patients except for HSC transplantation or palliative cures. Of note, JAK2 is found activated in the majority of them, even in absence of the $J A K 2$ V617F mutation, which is present in $50 \%$ of the patients [26]. JAK2 mutational status or allele burden have been related to clinical signs of the disease like splenomegaly, transformation to Acute Myeloid Leukemia (AML) and overall survival [27-29], thus pointing to JAK2 inhibition as a promising strategy to treat MF. After a first study which evaluated the efficacy of ruxolitinib in preclinical models of JAK2 V617F positive MPN [28], a phase I-II [30] and two phase III clinical trials (COMFORT I and II) were carried out with positive results [31, 32]. In the first case, 153 patients with $J A K 2$ V617F positive or JAK2 V617F negative primary MF, post-essential thrombocythemia MF, or post-PV MF were enrolled. $44 \%$ of them showed reduction of splenomegaly and the majority of them, who received the drug at a dose of $10 \mathrm{mg}$ twice daily to $25 \mathrm{mg}$ twice daily, had more than 50\% improvement in total or individual symptom scores according to the Myelofibrosis Symptom Assessment Form (MFSAF) [30]. In both COMFORT I (ruxolitinib vs. placebo) [29] and COMFORTII (ruxolitinib vs best available therapy) studies [33], patients receiving oral ruxolitinib showed reduced splenomegaly at week 48 and an improvement of debilitating symptoms and quality of life [30, 32, 34-37]. 5-years follow up analysis showed an advantage in terms of overall survival for both COMFORTI and COMFORTII studies: medium overall survival was not reached for ruxolitinib, while it was 3.8 years for placebo group [36] and 4.1 years for the group receiving the best available treatments [37]. Moreover, ruxolitinib has also been used in phase III clinical trials with patients affected by PV intolerant or resistant to hydroxyurea demonstrating an effectiveness in reducing splenomegaly and clinical symptoms [38-41]. However, ruxolitinib treatment induces a complete response only in a small percentage of patients [40, 41]. Concerning ET patients intolerant or resistant to hydroxycarbamide, ruxolitinib did not improve treatment efficacy in comparison with the best available therapy [42-44]. This result suggests that the effectiveness of targeted 
treatments depends not only on the presence of specific mutations, but also on the peculiar features of the pathology.

The lack of a complete response in MPN patients treated with ruxolitinib might be due to the activation of collateral oncogenic pathways, like the one of c-Jun Nterminal kinase (JNK) or PI 3-kinase (PI3K)/AKT serine/ threonine kinase (AKT)/ mammalian target of rapamycin (mTOR) pathway [45]. Consistent with this, PI3K, $\mathrm{AKT}$ and mTOR inhibitors have been tested alone or in combination with ruxolitinib demonstrating synergistic effects in MPN cells [46-50]. STAT5 plays a crucial role in JAK2-driven myeloproliferation by inducing the expression of proteins promoting cell division, cytokines independent growth and cell survival like c-MYC, CYCLIN D2, ID1, BCL-XL and MCL-1 [51]. In vivo experiments demonstrated that JAK2 V617F requires STAT5 to induce MPN in mice, while STAT3 was found to be dispensable [52]. However, STAT5 specific inhibitors are not yet suitable for clinical applications [53]. It has been shown that JAK2 and PI3K/AKT/mTOR regulate STAT5 activation by inducing its phosphorylation on different residues and that ruxolitinib is ineffective in reducing STAT5 phosphorylation driven by the PI3K pathway [54]. Indeed, combined inhibition of JAK2, PI3K and mTOR in JAK2 V617F mutated cells causes reduction of both JAK2 and PI3K mediated STAT5 phosphorylation, impairment of the clonogenic potential of JAK2 V617Fmutated hematopoietic progenitors cells and reduced splenomegaly and myeloid cells infiltration in Jak2 V617F knock-in mice [54]. These studies suggest the importance of PI3K/AKT/mTOR axis in myeloproliferative diseases; however, the effects of the inhibition of these molecules in aCML pre-clinical models and patients still need to be evaluated.

Even in absence of JAK2 mutations, MPN cells use different strategies to induce JAK2 hyperactivation and trigger myeloid expansion [15]. It has been shown that CALR gene, encoding for calreticulin, is mutated in the vast majority of $J A K 2$ V617F negative MPN patients $[55,56]$. Calreticulin is a $\mathrm{Ca}^{++}$binding protein with chaperone activity located in the endoplasmic reticulum $[56,57]$. Mutant calreticulin acquires the ability to bind to the thrombopoietin receptor (MPL receptor) in the ER and then on the cell surface, inducing ligand-independent activation of the JAK2/STAT/PI3K and MAPK pathways [15]. However, CALR mutations have been found rarely in aCML patients $[11,55,56]$. Mutations in genes coding for other JAK2 activators, like the TPO-R [58] and G-CSF-R, have been found in myeloproliferative disorders. CSF3R gene encodes for the Granulocyte colony-stimulating factor receptor (G-CSF-R), the more relevant JAK2-upstream regulator in aCML. This receptor provides the signal for growth and differentiation of granulocytes through the binding to its ligand: the granulocyte colony-stimulating factor 3 (G-CSF; CSF3) [59-61]. Two types of mutations were originally identified in a cohort of 27 patients with CNL or aCML [62]: membrane proximal mutations (T615A and T618I), which confer ligand-independent growth, and nonsense or frameshift mutations, resulting in the truncation of the cytoplasmic region with consequent alteration of granulocytic differentiation and proliferation [62-64]. Besides the JAK/STAT pathway [65, 66], G-CSF-R also signals through the tyrosine-protein kinase SYK and the SRC family kinase (SFK) LYN $[67,68]$. When receptors carry truncating mutations, they signal through SFKs rendering the cells sensible to the multikinase inhibitor dasatinib. In contrast, when carrying the membrane proximal mutations, the receptor signals through the JAK/STAT pathway and in this case cells are sensitive to ruxolitinib [62]. In a first report, Maxson and colleagues found CSF3R mutations in 59\% of patients with CNL or aCML, while subsequent analysis indicated that the activating CSF3R T618I mutation is present in < $10 \%$ of cases of aCML $[11,69,70]$. Thanks to these studies, the identification of CSF3R T618I in the context of neutrophilic leukocytosis is now strongly associated with a diagnosis of CNL, where it is present in approximately $80 \%$ of patients [69]. In line with this evidence, mice transplanted with hematopoietic cells expressing CSF3R T618I develop a CNL-like disease characterized by neutrophil expansion in the peripheral blood and bone marrow and neutrophil infiltration in spleen and liver [71]. Administration of ruxolitinib to these mice results in reduction of WBC, decreased spleen weight and increased body weight [71]. Another report described the acquisition of CSF3R mutations (both the proximal mutation T618I and a truncating mutation $\mathrm{Q} 739^{*}$ ) in a patient progressing from MPN unclassifiable to aCML [72]. An alternative membrane proximal mutation, the $\mathrm{T} 640 \mathrm{~N}$, was described in a patient with MDS progressing to aCML-like disorder. This mutation confers ligand-independent growth, mimicking the CSF3R T618I, and sensitivity to ruxolitinib treatment [73]. The potentiality of ruxolitinib for CSF3R T618Imutated patients was demonstrated with two case reports: a 75-years old man and a 11-years old girl with aCML. The man, who was refractory to hydroxyurea treatment, displayed decreased WBC, reduction of the spleen volume, increased haemoglobin and platelets count after ruxolitinib treatment [74]. The young girl received ruxolitinib for 8 weeks and the good response to the treatment allowed her to be bridged to allogenic HSC transplantation [75]. Currently, a phase II study (NCT02092324) is evaluating the efficacy of ruxolitinib treatment in patients with CNL or aCML. These evidences suggest that the evaluation of the presence of JAK2 or CSF3R mutations in aCML patients could open the way for specific therapeutic interventions (Fig. 1). 


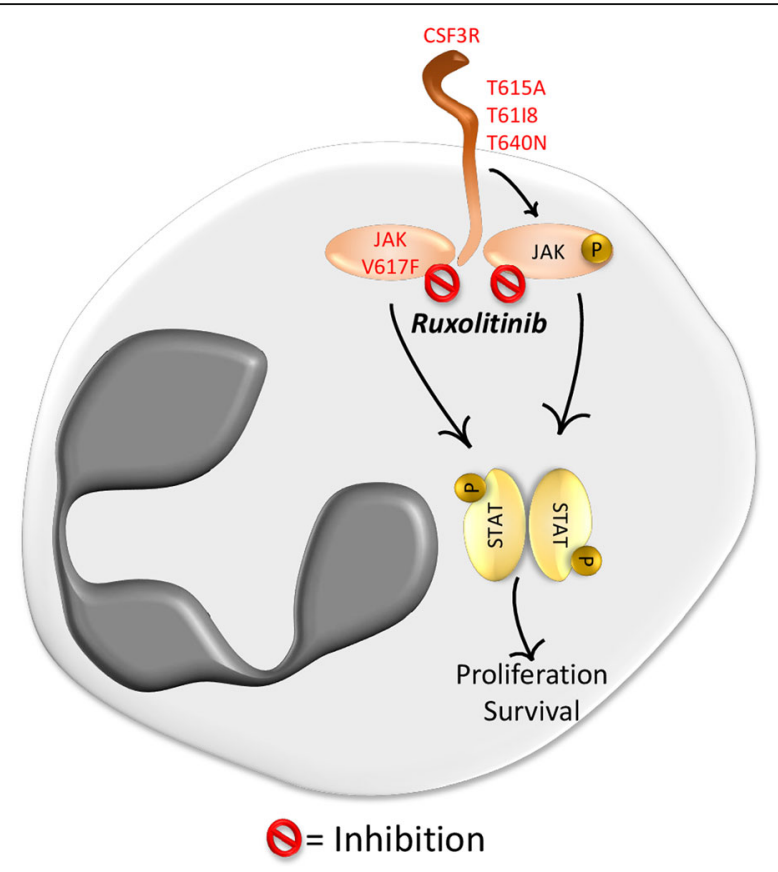

Fig. 1 JAK2 and CSF3R mutated patients can benefit of ruxolitinb treatment. In basal conditions, JAK2 signaling is initiated by the binding of cytokines to the associated receptors. Once activated, JAK phosphorylates STAT proteins inducing their dimerization and translocation to the nucleus, where they activate or suppress gene transcription. In the presence of JAK2 V617F mutation, the JAK/STAT pathway is constitutively activated. CSF3R is known to signal through the JAK tyrosine kinase pathway. CSF3R membrane proximal mutations, such as T615A, T618I and T640 N, constitutively activate JAK-mediated signaling and are sensitive to its kinase inhibitor ruxolitinib

\section{The RAS pathway}

RAS proteins are small GTPases involved in signal transduction and frequently mutated in human cancers. There are three major isoforms (HRAS, KRAS, NRAS) which, in their GTP-bound form, signal through the MAPK and the PI3K pathways [76], promoting cancer cell survival and proliferation. Mutant RAS recruits RAF to the plasma membrane and activates the downstream Mitogen-activated protein kinase kinase (MEK)/ Mitogenactivated protein kinase 3 (ERK) signaling cascade [77]. Mutations in the KRAS and NRAS genes (but rarely in the $H R A S$ gene) are frequently identified in myeloid disorders (15\%-60\%), including AML [78, 79], aCML [11], CMML [80] and JMML [81]. For decades scientists tried to develop effective strategies to target $R A S$-mutant cancers even if targeting RAS itself has proven to be difficult [77]. One of the attempts was to use nucleotide analogs to trap mutant RAS in an inactive state but this approach failed because of the high concentrations of GTP that make competition impossible. Screenings for compounds that restore GTPase hydrolysis to mutant RAS, in the presence or absence of GAP, also failed [77]. Given the difficulties in targeting RAS, many researches focused on inhibiting downstream effectors in the MAPK pathway. B-RAF has been tested as molecular target especially in solid tumors, as melanoma, where it is mutated in $50 \%$ of the cases. Therapies with RAF inhibitors lead to some degree of tumor regression, but poor response or acquired resistance are also common $[82,83]$. Resistance is often due to a paradoxical activation of ERK, mainly in $R A S$-mutant cancers [84-86]. The results obtained with RAF inhibitors, led to the postulation that MEK1/2 are better therapeutic targets in RAS mutated hematological malignancies. Oncogenic RAS is sufficient to initiate myeloid leukemogenesis in mice: the expression of mutant K-RasG12D protein from the endogenous murine locus rapidly induces a fatal myeloproliferative disorder with $100 \%$ penetrance [87]. The efficacy of MEK inhibitors on myeloid NRAS/KRAS mutated leukemic cells have been tested using two different mouse models: a Mx1-Cre, KrasLSL-G12D mice, which develop a fatal myeloproliferative neoplasm [88] and mice transplanted with NRAS mutated AML cells (NrasG12D AML cells) [89]. In the first study mice were treated with the MEK inhibitor PD0325901 [90] which prolonged survival and reduced leukocyte count, anemia and splenomegaly [88]. In the second study, mice were treated with two different MEK inhibitors: PD0325901 and trametinib (also known as GlaxoSmithKline 1,120,212). Trametinib is an oral, selective and allosteric inhibitor of MEK1/MEK2 approved by the US Food and Drug Administration as a single agent or in combination with the B-RAF inhibitor dabrafenib (Tafinlar; GlaxoSmithKline) for the treatment of unresectable or metastatic melanoma with a BRAF V600E/V600 K mutation [91]. Both MEK inhibitors significantly improved the survival of recipient mice by inhibiting AML proliferation [89]. Trametinib efficacy was then tested in an open-label, dose-escalation, nonrandomized, multicentre phase $1 / 2$ study (GlaxoSmithKline study MEK111759; ClinicalTrials.gov identifier NCT00920140) [92]. 97 patients (AML, 75\%; high-risk MDS, 12\%; CMML, 11\%; and ALL, 1\%) were enrolled in the study: 13 patients had KRAS mutations, and 54 patients had NRAS mutations. Among RAS mutated patients, the overall response rate was $21 \%$ with reduction in bone marrow and peripheral blasts. However, the response did not translate into survival advantage, probably due to the fact that $R A S$ mutations emerge late during leukemogenesis and that many of the patients enrolled were already resistant to previous therapies, possibly due to the presence of different subclones with various levels of dependence on the MAPK pathway [92]. For what concern aCML, KRAS/NRAS mutations were identified in $7 / 20$ patients (35\%) [11]. A case report described a 81-years-old male with heterozygous NRAS G12D mutation who, after receiving trametinib, 
showed improvements in his blood count and a durable disease control for 14 months of follow-up [93].

This unique clinical report on an aCML patient treated with trametinib, together with the results obtained in preclinical studies, highlight the need for clinical trials to test the efficacy of MEK inhibitors in larger cohorts of RAS-mutated aCML patients (Fig. 2). Of note, RAS also activates $\mathrm{PI} 3 \mathrm{~K} / \mathrm{AKT} / \mathrm{mTOR}$, which can represent an axis promoting proliferation and survival of cancer cell. For this reason, combined treatment using both MEK inhibitors and PI3K/AKT/mTOR inhibitors could be more effective in inducing tumor regression and many clinical trials are already testing this possibility in different contexts [94]. Interestingly, treatment with GDC-0941, an orally available inhibitor of class I PI3K isoforms, extended Mx1-Cre, KrasLSL-G12D mouse survival, inducing reduction of anemia, splenomegaly and leucocytosis, by inhibiting simultaneously MAPK and PI3K signaling [95].

\section{The ROCK pathway}

ROCK $1 / 2$ are two multifunctional proteins with $65 \%$ of overall identity [96]. They play different roles in the cells: from regulating cytoskeletal rearrangements to taking part in signaling pathways leading to apoptosis and proliferation [97-105]. ROCK signaling deregulation is emerging as a key feature in myeloid leukemias. Mali and colleagues demonstrated that ROCK is constitutively

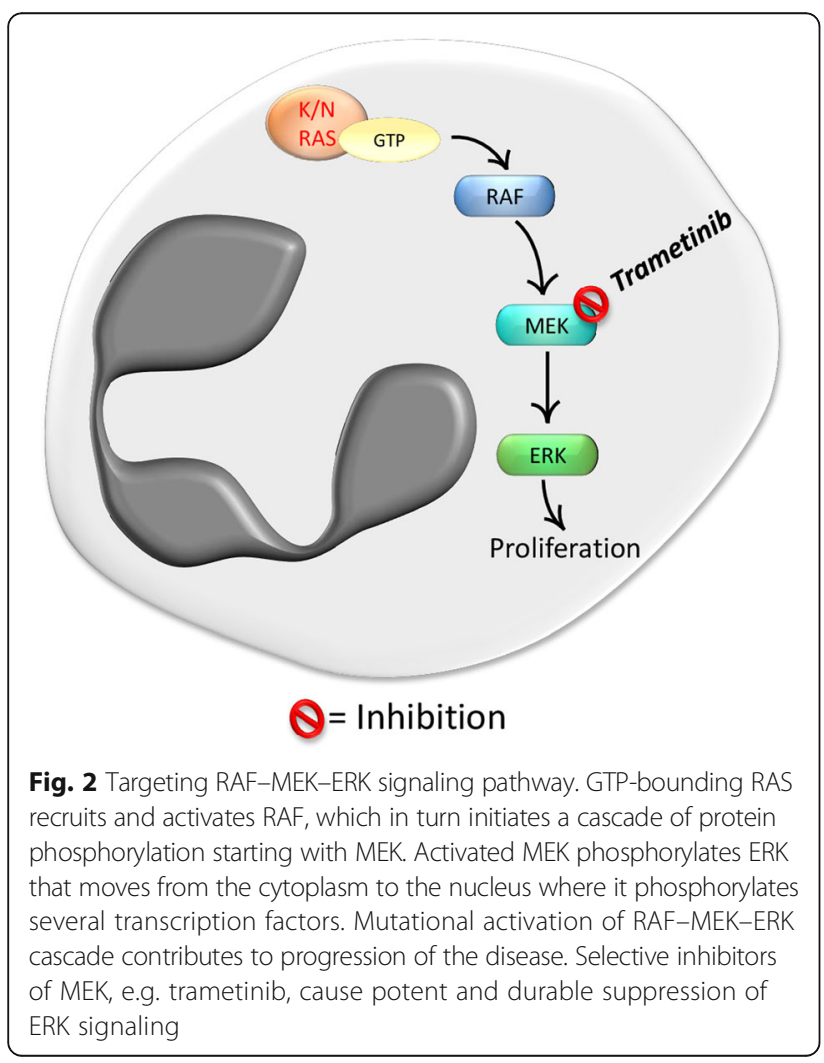

activated in cells harboring oncogenic forms of KIT, FLT3, and BCR-ABL [101]. ROCK inhibition by Y-27632 or $\mathrm{H}-1152$ strongly reduces leukemic cell proliferation $[21,101,106,107]$ demonstrating that mutant tyrosine kinase receptors are able to induce leukemic transformation, at least in part, through ROCK signaling. A subsequent report demonstrated that ROCK downregulation strongly impairs cell proliferation also in human CD34+ AML cells. In fact, if primary AML cells silenced for ROCK are xenotransplanted in mice, human chimerism is strongly reduced compared to control cells, demonstrating that the ROCK activity is required for oncogenic proliferation in vivo [108]. Data from our laboratory added a little piece to the puzzle by discovering the role of morgana, an ubiquitous protein coded by the CHORDC1 gene, in myeloproliferation [100, 109-111]. While Chordc1 knock-out mice die early during embryogenesis, heterozygous mice are vital, but develop spontaneously a fatal and transplantable myeloproliferative disease resembling human aCML $[15,112]$. Morgana is a chaperone protein able to inhibit both ROCK1 [100] and ROCK2 [110], and recently found to be required for NF- $\mathrm{kB}$ signaling [113]. Chordc1 heterozygous mice, expressing half of the normal amount of morgana, show Rock hyperactivation in the bone marrow preceding the onset of the disease. Importantly, leukemic bone marrow cells treated ex vivo with the ROCK inhibitor fasudil, already in clinical use in Japan for the treatment of cerebral vasospasm, show a significant induction of apoptosis compared to control cells [112] (Fig. 3). The downregulation of morgana and the subsequent hyperactivation of ROCK has been found in 16\% of patients with $B C R-A B L$ positive CML and in 5 out of 5 patients with aCML [112]. BCR-ABL positive CML patients expressing low morgana levels hardly achieve the major molecular response (MMR) after 18 months of treatment with the first line tyrosine kinase inhibitor imatinib. Low morgana expression levels confer resistance to imatinib in in vitro treatment of $B C R-A B L$ positive bone marrow cells from CML patients. The combination of imatinib with the ROCK inhibitor fasudil is sufficient, in vitro, to restore an optimal apoptotic response demonstrating that targeting BCR-ABL and ROCK signaling simultaneously could be a therapeutic strategy for BCR-ABL positive patients expressing low morgana levels. The beneficial effect of fasudil on CML and aCML patients still need to be tested.

Interestingly, JAK2, RAS and ROCK pathways are strictly interconnected: RAS binds to and activates PI3K, while JAK2 activates RAS and PI3K pathways [114] and in turn, PI3K can activate ROCK [101]. This signaling network could generate a vicious circle promoting proliferation, survival and poor treatment response in MPN. Combining inhibitors for the different network components is an interesting possibility to increase treatment 


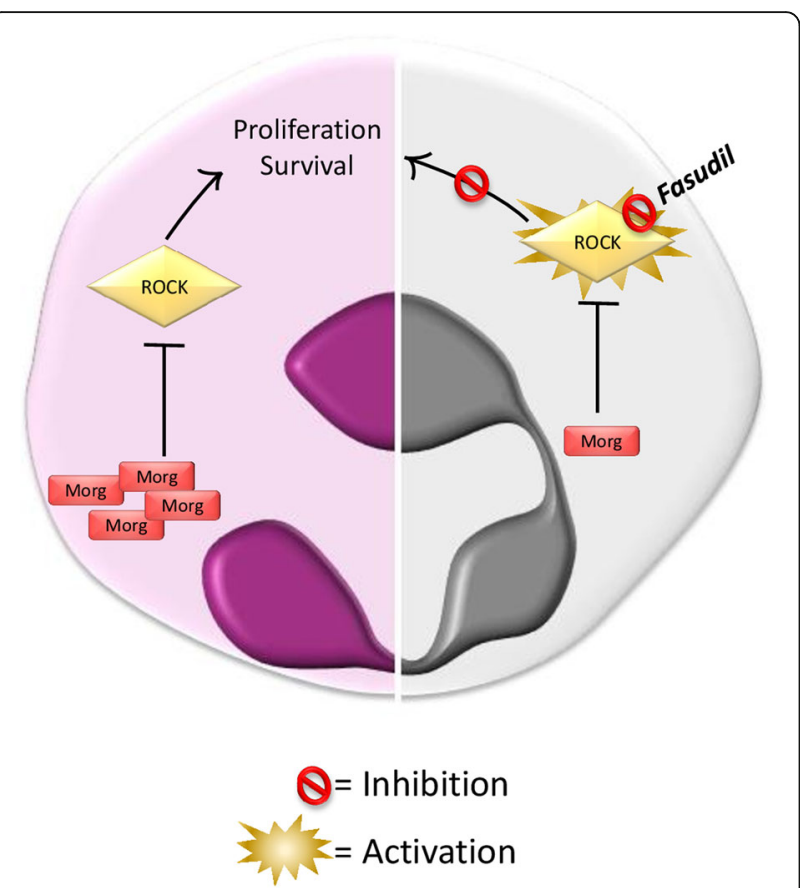

Fig. 3 Fasudil treatment for Morganalow leukemic cells. A diminished Morgana expression induces ROCK hyperactivation. ROCK plays a key role in multiple cell signaling processes, inducing proliferation and survival in myeloid cells. ROCK inhibition, through fasudil, results in increased apoptosis of leukemic cells

efficacy and overcome resistance. Of note, a currently enrolling clinical trial (NCT02493530) will test the combination of ruxolitinib and a PI3K $\delta$ inhibitor and aCML patients will be also enrolled in its expansion stage.

\section{Genetic alterations in aCML}

In the past few years, scientists' attention focused on genetic alterations characterizing aCML. The development of next generation sequencing (NGS) techniques allowed the identification of low recurrent mutations, translocations, indels and splicing variants in a number of genes [6, 70, 115-119]. These studies demonstrated that aCML is predominantly a $J A K 2$ V617F negative neoplasm $[120,121]$ with mutation in the gene found in $4 \%$ to $8 \%$ of patients $[11,14,70]$. However, other genes have been found mutated at different frequencies, mainly ASXL1 (28\%), TET2 (16\%), NRAS (16\%), SETBP1 (12\%), RUNX1 (12\%), ETNK1 (8\%), PTPN11 (4\%), CSF3R (3\%) [70, 115$117,119,122,123]$. These findings may have crucial relevance in directing personalized therapies, since aCML-associated genetic alterations could be susceptible to specific therapeutic approaches, directly targeting the mutant proteins or their associated pathways. NRAS, $J A K 2$ and CSF3R mutations, have been previously discussed and since they directly impact on the MAPK and JAK/STAT pathways, they are obvious candidates for targeted therapies. However, other two mutations are predicted to activate the signaling pathways discussed above.

SETBP1 encodes a protein named SET binding protein 1 (SEB) for which the precise function is still to be discovered. Mutations in a particular 12 bp hot spot disrupt a degron signal, leading to SEB overexpression [124]. It has been demonstrated that SEB impacts on AKT and MAPK pathways, responsible for cell proliferation and survival [125]. In particular, SEB binds to the SET nuclear oncoprotein protecting it from protease cleavage. In turn, SET represses PP2A activity $[126,127]$ that inhibits AKT and MAPK pathways. When SEB is mutated, it accumulates in the cells and, through SET, decreases PP2A activity, leading to increased cellular proliferation [117].

PTPN11 gene encodes for SHP2 (Src-homology-2 domain containing protein tyrosine phosphatase), a protein tyrosine phosphatase (PTPase) acting downstream to growth factor receptors. Mutations in the PTPN11 gene result in constitutively activated RAS. In fact, when SHP2 is mutated it activates guanine nucleotide exchange factors (GEFs), necessary for the conversion of GDP-RAS into GTP-RAS [14, 128]. Interestingly, SHP2 is phosphorylated by JAK1 and JAK2 and the phosphorylated form of SHP2 binds to GRB2 and activates RAS [129]. Moreover, JAK2, PTPN11 and RAS mutations were identified as mutually exclusive in MDS, suggesting their participation to the same pathway [130]. Given the central role of RAS mutation in MPN and the convergence of SETBP1, PTPN11 and JAK2 encoded proteins on MAPK pathway overactivation, patients carrying mutations in these genes could benefit from treatment with MEK inhibitors.

However, a number of genes mutated in aCML encodes for biosynthetic enzymes, transcription factors and epigenetic modifiers. These proteins are apparently unrelated with the signal transduction molecules previously discussed and their exact role in the onset of the pathology is still unclear.

ETNK1, for example, encodes an ethanolamine kinase (EKI 1) which phosphorylates ethanolamine to phosphoethanolamine in the phosphatidylethanolamine biosynthesis pathway. Two recurrent point mutations impairing the catalytic activity of the kinase have been described in ETNK1 gene in aCML [131]. The phosphatidylethanolamine biosynthesis pathway is involved in many biochemical processes like definition of membrane architecture, anchoring of proteins to the plasma membrane, mitochondria biogenesis, autophagy and progression to cytokinesis during cell division [116, 132, 133]. Due to the fact that EKI 1 contributes to different processes in the cell, the mechanisms by which the mutant protein induces myeloproliferation have not yet been clarified.

RUNX1 encodes the alpha subunit of the core binding factor (CBF) complex. This complex activates and represses transcription of genes involved in growth, survival 
and differentiation pathways in hematopoietic cells, maintaining the proper balance among different lineage progenitors [134]. This gene is recurrently mutated in a variety of hematological malignancies due to chromosomal translocations and somatic mutations. Mono- and biallelic RUNX1 mutations have been described in aCML [14]. Some mutations cause inactivation of the protein, while others induce a dominant negative activity [135]. However, the mechanism through which the mutant RUNX1 induces myeloid expansion is still to be understood.

The TET dioxygenases, TET1, TET2, and TET3, catalyze the transfer of an oxygen atom to the methyl group of 5-methylcytocine $(5-\mathrm{mC})$, converting it to 5hydroxymethylcytocine $(5-\mathrm{hmC})[136,137]$. This modification, in turn, promotes locus-specific reversal of DNA methylation, impacting on DNA methylation landscape [138]. TET2 is frequently mutated in both myeloid and lymphoid malignancies [14, 122, 139-142] resulting in a wide hypermethylation phenotype [143], but, again, the precise pathways responsible for the phenotype downstream this global genome alteration have not been dissected. The hypomethylating agent decitabine, approved by FDA for the treatment of MDS and CMML, have been tested in aCML patients (regardless of TET2 mutational status) with some positive results, even if on small cohorts of patients, and deserves better investigations [144-147].

ASXL1 (Additional of sex combs-like 1) plays a role in the recruitment of the Polycomb Repressive Complex 2 (PRC2) to its target sequences and takes part in the complex involved in deubiquitination of histone $\mathrm{H} 2 \mathrm{~A}$ lysine 119 (H2AK119) $[148,149]$. Mutations of the gene, identified in patients with AML, MPN and MDS, are associated with loss of ASXL1 expression [148]. Changes in the cell following ASXL1 mutations include: loss of PRC2-mediated gene repression, global loss of H3K27 trimethylation (H3K27me3) and derepression of the posterior HOXA cluster genes, including HOXA5-9, known to play a role in leukemogenesis [148].

All these proteins have in common a functional pleiotropy, since they can modify the expression of hundreds of genes or the functionality of many proteins in the cell. However, it is conceivable that, among the several deregulated events and pathways, few are responsible for leukemogenesis. In this view, it would be very useful to analyze the signaling pathways known to play a role in myeloproliferation in these mutational contexts in the final attempt to exploit targeted therapies with available inhibitors. Moreover, given that two or more mutations often occur simultaneously in aCML patients [119] combination therapies with different inhibitors seems, at least in theory, a promising approach.

Recently, two studies demonstrated that the percentage of healthy people showing clonal expansion of somatic mutations associated with hematologic diseases increases with age. The authors found that clonal haematopoiesis frequently involves DNMT3A, TET2, and ASXL1 mutant cells. Of note, somatic mutations were found to be associated with increased risk of hematological malignancies, as well as other adverse events [150, 151]. It will be tempting to envisage specific strategies for the prevention of the disease based on the mutations arising during the precancerous phases, however the predictive power of mutant hematopoiesis is low and additional biomarkers are needed to justify pharmacological intervention $[150,151]$.

\section{Conclusions}

aCML is a rare hematological disease for which no standard of care exists. NGS techniques have allowed in the past few years to highlight mutations in signal transduction proteins but also in proteins with pleiotropic functions, like transcription factors and chromatinmodifying enzymes [14]. These proteins may regulate the expression of thousands of genes simultaneously, deeply altering cell physiology. However, the precise mechanisms by which they induce and sustain tumorigenesis are still elusive. In particular, it is not known whether a single gene or a specific subgroup of genes controlled by these enzymes are responsible for cell transformation and through which mechanism. It is conceivable that wide alteration in gene expression could impact on the specific signal transduction pathways regulating proliferation and survival in haematopoietic cells. However, a wide analysis of signal transduction alterations in the different mutational contexts is still missing. This information will help to identify new therapeutic approaches in genetically defined subsets of diseases, but also to successfully repurposing existing drugs. As discussed in this review, JAK2, MEK and ROCK inhibitors might represent a treatment option for aCML patients. However, apart from encouraging preclinical studies and case reports, we still need multicenter randomized trials to test the potential benefits of these treatments in large cohorts of patients.

\footnotetext{
Abbreviations

ABL: Abelson murine leukemia viral oncogene homolog 1; aCML: Atypical Chronic Myeloid Leukemia; AKT: AKT serine/threonine kinase; ALL: Acute lymphoblastic leukemia; AML: Acute Myeloid Leukemia; ASXL1: Additional of sex combs-like 1; BCR: Breakpoint cluster region; BRAF: B-Raf proto-oncogene, serine/threonine kinase; CBF: Core Binding Factor; Chordc1: cysteine and histidine rich domain containing 1; CML: Chronic Myeloid Leukemia; CMML: Chronic Myelomonocytic Leukemia; CNL: Chronic Neutrophilic Leukemia; CSF3: colony stimulating factor 3; CSF3R: colony stimulating factor 3 receptor; DNA: deoxyribonucleic acid; EK 1: Ethanolamine Kinase 1; EPO-R: erythropoietin receptor; ERK1/2: extracellular signal-regulated kinases1/2; ET: Essential Thrombocythemia; FGFR1: fibroblast growth factor receptor 1; FLT3: fms related tyrosine kinase 3; G-CSF: Granulocyte-colony stimulating factor; GDP: guanosine diphosphate; GEFs: Guanine nucleotide exchange factors; GTP: Guanosine-5'-triphosphate; HOXA: homeobox A cluster; HRAS: Harvey RAS oncogene homolog; HSC: Hematopoietic Stem Cell; JAK2: Janus kinase 2; JMML: Juvenile Chronic Myelogenous Leukemia; JNK: c-Jun N-terminal kinase; KRAS: Kirsten RAS oncogene homolog; MAPK: mitogen-activated protein kinase; MDS: Myelodysplastic syndrome; MDS/MPN-U: Myelodysplastic/Myeloproliferative neoplasms unclassifiable;
} 
MF: Myelofibrosis; MPN: Myeloproliferative neoplasm; NGS: Next Generation Sequencing; NRAS: neuroblastoma RAS viral oncogene homolog; PDGFRA/B: Platelet Derived Growth Factor Receptor A/B; PI3K: Phosphatidylinositol-4,5-bisphosphate 3-kinase; PP2A: protein phosphatase 2, alpha isoform; PRC2: Polycomb Repressive Complex 2; PTPase: Protein Tyrosine Phosphatase; PTPN11: protein tyrosine phosphatase, non-receptor type 11; PV: Polycythaemia Vera; ROCK1/2: Rho associated coiled-coil containing protein kinase 1/2; RUNX1: runt related transcription factor 1; SEB: SET binding protein 1; SHP2: Src-homology-2 domain containing protein tyrosine phosphatase; STAT: Signal transducer and activator of transcription; SYK: spleen associated tyrosine kinase; TET1/2/3: Ten-eleven translocation methylcytosine dioxygenase 1/2/3; TPO-R: thrombopoietin receptor; WBC: White Blood Cells; WHO: World Health Organization

\section{Acknowledgements}

Not applicable

\section{Funding}

This work was supported by AIRC 2014 (IG 15880) to MB and Progetto Giovani Ricercatori 2011 (GR-2011-02351167) to AM.

\section{Authors' contributions}

SR and GC reviewed available literature and wrote the manuscript. PP drew the figures. $\mathrm{AM}$ and $\mathrm{MB}$ discussed and revised the manuscript. All the authors read and approved the final manuscript.

\section{Competing interests}

The authors declare that they have no competing interests.

\section{Publisher's Note}

Springer Nature remains neutral with regard to jurisdictional claims in published maps and institutional affiliations.

\section{Author details}

'Department of Molecular Biotechnology and Health Sciences, University of Torino, 10126 Torino, Italy. ${ }^{2}$ Department of Clinical and Biological Sciences, University of Torino, 10043 Orbassano, Italy.

Received: 27 October 2017 Accepted: 1 February 2018 Published online: 19 February 2018

\section{References}

1. Chereda B, Melo J V. Natural course and biology of CML. Ann. Hematol. Springer Berlin Heidelberg; 2015 [cited 2017 Sep 13];94:107-121. Available from: http://link.springer.com/10.1007/s00277-015-2325-z.

2. Apperley JF. Chronic myeloid leukaemia. Lancet (London, England). 2015 [cited 2017 Sep 13];385:1447-1459. Available from: http://linkinghub.elsevier. com/retrieve/pii/S0140673613621200.

3. Vardiman JW, Harris NL, Brunning RD. The World Health Organization (WHO) classification of the myeloid neoplasms. [cited 2017 Mar 15]; Available from: http://www.bloodjournal.org/content/bloodjournal/100/7/2292.

4. Vardiman JW, Thiele J, Arber DA, Brunning RD, Borowitz MJ, Porwit A, et al The 2008 revision of the World Health Organization (WHO) classification of myeloid neoplasms and acute leukemia: rationale and important changes. Blood. 2009 [cited 2017 Feb 21];114:937-951. Available from: http://www. ncbi.nlm.nih.gov/pubmed/19357394.

5. Arber DA, Orazi A, Hasserjian R, Thiele J, Borowitz MJ, Le Beau MM, et al. The 2016 revision to the World Health Organization classification of myeloid neoplasms and acute leukemia. Blood. 2016;127:2391-405.

6. Gotlib J, Maxson JE, George TI, Tyner JW. The new genetics of chronic neutrophilic leukemia and atypical CML: implications for diagnosis and treatment. Blood. 2013;122:1707-11.

7. Galton DAG. Haematological differences between chronic granulocytic Leukaemia, atypical chronic myeloid Leukaemia, and chronic Myelomonocytic Leukaemia. Leuk Lymphoma. 1992;7:343-50. Available from: http://www.tandfonline.com/doi/full/10.3109/10428199209049789.

8. Bennett JM, Catovsky D, Daniel MT, Flandrin G, Galton DA, Gralnick H, et al. The chronic myeloid leukaemias: guidelines for distinguishing chronic granulocytic, atypical chronic myeloid, and chronic myelomonocytic leukaemia. Proposals by the French-American-British Cooperative Leukaemia
Group. Br. J. Haematol. 1994 [cited 2017 Feb 21];87:746-754. Available from: http://www.ncbi.nlm.nih.gov/pubmed/7986717.

9. Oscier DG. Atypical chronic myeloid leukaemia, a distinct clinical entity related to the myelodysplastic syndrome? Br. J. Haematol. 1996 [cited 2017 Feb 21];92: 582-586. Available from: http://www.ncbi.nlm.nih.gov/pubmed/8616021.

10. Kurzrock R, Bueso-Ramos CE, Kantarjian H, Freireich E, Tucker SL, Siciliano M, et al. BCR Rearrangement-Negative Chronic Myelogenous Leukemia Revisited. J. Clin. Oncol. 2001 [cited 2017 Feb 28];19:2915-2926. Available from: http://www.ncbi.nlm.nih.gov/pubmed/11387365.

11. Wang SA, Hasserjian RP, Fox PS, Rogers HJ, Geyer JT, Chabot-richards D, et al. Atypical chronic myeloid leukemia is clinically distinct from unclassi fi able myelodysplastic / myeloproliferative neoplasms. Blood. 2015;123:2645-52.

12. Gotlib J. How I treat atypical chronic myeloid leukemia. Blood. 2017;129:838-45.

13. Breccia M, Biondo F, Latagliata R, Carmosino I, Mandelli F, Identification AG. Of risk factors in atypical chronic myeloid leukemia. Haematologica. 2006;91:1566-8

14. Zoi K, Cross NCP. Molecular pathogenesis of atypical CML, CMML and MDS/ MPN-unclassifiable. Int J Hematol. 2015;101:229-42.

15. Morotti A, Rocca S, Carrà G, Saglio G, Brancaccio M. Modeling myeloproliferative neoplasms: from mutations to mouse models and back again. Blood rev. Elsevier Ltd; 2016;3:1-12. Available from: https://doi.org/10. 1016/j.blre.2016.11.004.

16. Martelli AM, Evangelisti C, Chiarini F, Grimaldi C, Cappellini A, Ognibene A, et al. The emerging role of the phosphatidylinositol 3-kinase/Akt/ mammalian target of rapamycin signaling network in normal myelopoiesis and leukemogenesis. Biochim. Biophys. Acta. 2010 [cited 2017 Sep 18];1803: 991-1002. Available from: http://www.ncbi.nlm.nih.gov/pubmed/20399811.

17. Geest CR, Coffer PJ. MAPK signaling pathways in the regulation of hematopoiesis. J. Leukoc. Biol. 2009 [cited 2017 Sep 18];86:237-250. Available from: http://www.ncbi.n/m.nih.gov/pubmed/19498045.

18. McLemore ML, Grewal S, Liu F, Archambault A, Poursine-Laurent J, Haug J, et al. STAT-3 activation is required for normal G-CSF-dependent proliferation and granulocytic differentiation. Immunity. 2001 [cited 2017 Sep 18];14:193-204. Available from: http://www.ncbi.n/m.nih.gov/pubmed/11239451.

19. Gits J, Leeuwen D van, Carroll HP, Touw IP, Ward AC. Multiple pathways contribute to the hyperproliferative responses from truncated granulocyte colony-stimulating factor receptors. Leukemia. Publ. online 26 Oct. 2006; | doi: https://doi.org/10.1038/sj.leu.2404448. Nature Publishing Group; 2006 [cited 2017 Sep 18];20:2111. Available from: https://www.nature.com/leu/ journal/v20/n12/full/2404448a.html.

20. Li B, Gale RP, Xiao Z. Molecular genetics of chronic neutrophilic leukemia, chronic myelomonocytic leukemia and atypical chronic myeloid leukemia. J. Hematol. Oncol. BioMed Central; 2014 [cited 2017 Apr 26];7:93. Available from: http://www.ncbi.nlm.nih.gov/pubmed/25498990.

21. Mali RS, Kapur R. Targeting rho associated kinases in leukemia and myeloproliferative neoplasms. Oncotarget. 2012;3:909-10.

22. Harrison DA. The JAK/STAT Pathway. Cold Spring Harb Perspect Biol 2012[cited 2018 Jan 19];4:a011205 Available from: http://cshperspectives. cshlp.org/content/4/3/a011205.

23. Jones A V., Kreil S, Zoi K, Waghorn K, Curtis C, Zhang L, et al. Widespread occurrence of the JAK2 V617F mutation in chronic myeloproliferative disorders. Blood. 2005 [cited 2017 Apr 26];106:2162-2168. Available from: http://www.bloodjournal.org/content/106/6/2162.long?sso-checked=true.

24. Levine RL, Loriaux M, Huntly BJP, Loh ML, Beran M, Stoffregen E, et al. The JAK2V617F activating mutation occurs in chronic myelomonocytic leukemia and acute myeloid leukemia, but not in acute lymphoblastic leukemia or chronic lymphocytic leukemia. Blood. 2005 [cited 2017 Apr 26];106:3377-3379. Available from: http://www.bloodjournal.org/content/106/10/3377.long.

25. Pardanani A, Tefferi $A$. Is there a role for JAK inhibitors in BCR-ABL1 -negative myeloproliferative neoplasms other than myelofibrosis? Leuk. Lymphoma. Taylor \& Francis; 2014 [cited 2017 Apr 26];55:2706-2711. Available from: http://www.tandfonline.com/doi/full/10.3109/10428194.2014.985159.

26. Barosi G, Bergamaschi G, Marchetti M, Vannucchi AM, Antonioli E, Massa M, et al. JAK2 V617F mutational status predicts progression to large splenomegaly and leukemic transformation in primary myelofibrosis JAK2 V617F mutational status predicts progression to large splenomegaly and leukemic transformation in primary myelofibrosis. Blood. 2012;110:4030-6.

27. Tefferi A, Lasho TL, Huang J, Finke C, Mesa RA, Li CY, et al. Low JAK2V617F allele burden in primary myelofibrosis, compared to either a higher allele burden or unmutated status, is associated with inferior overall and leukemia-free survival. Leukemia. 2008;22:756-61. 
28. Quintás-cardama A, Vaddi K, Liu P, Manshouri T, Li J, Scherle PA, et al. INCB018424 : therapeutic implications for the treatment of myeloproliferative neoplasms preclinical characterization of the selective JAK1 / 2 inhibitor INCB018424 : therapeutic implications for the treatment of myeloproliferative neoplasms. Blood. 2014;115:3109-17.

29. Verstovsek S, Mesa RA, Gotlib J, Levy RS, Gupta V, DiPersio JF, et al. A Double-Blind, Placebo-Controlled Trial of Ruxolitinib for Myelofibrosis. N. Engl. J. Med. 2012;366:799-807. Available from: http://www.nejm.org/doi/ abs/10.1056/NEJMoa1110557.

30. Verstovsek S, Ph D. Safety and Efficacy of INCB018424, a JAK1 and JAK2 inhibitor, in myelofibrosis safety and efficacy of INCB018424, a JAK1 and JAK2 inhibitor, in myelofibrosis. N Engl J Med 2010;363:1117-1127.

31. Verstovsek S, Mesa RA, Gotlib J, Levy RS, Gupta V, DiPersio JF, et al. Efficacy, safety and survival with ruxolitinib in patients with myelofibrosis: results of a median 2-year follow-up of COMFORT-I. Haematologica. Haematologica; 2013 [cited 2017 Dec 27];98:1865-1871. Available from: http://www.ncbi. nlm.nih.gov/pubmed/24038026

32. Verstovsek S, Mesa RA, Gotlib J, Levy RS, Gupta V, Dipersio JF, et al. Efficacy, safety, and survival with ruxolitinib in patients with myelofibrosis: results of a median 3-year follow-up of COMFORT-I. Haematologica. 2015;100:479-88.

33. Harrison C, Kiladjian J-J, Al-Ali HK, Gisslinger H, Waltzman R, Stalbovskaya V, et al. JAK Inhibition with Ruxolitinib versus Best Available Therapy for Myelofibrosis. n engl j med. 2012 [cited 2017 Dec 27];3669:787-798. Available from: http://www.nejm.org/doi/pdf/10.1056/NEJMoa1110556.

34. Cervantes F, Kiladjian J, Niederwieser D, Sirulnik A, Stalbovskaya V. et al. Long-Term Safety, Efficacy, and Survival Findings From Comfort-Il, a Phase 3 Study Comparing Ruxolitinib with Best Available Therapy (BAT) for the Treatment of Myelofibrosis (MF). Blood 2012 120:801; Available from: http:// www.bloodjournal.org/content/120/21/801.

35. Cervantes F, Vannucchi AM, Kiladjian J-J, Al-Ali HK, Sirulnik A, Stalbovskaya V, et al. Three-year efficacy, safety, and survival findings from COMFORT-II, a phase 3 study comparing ruxolitinib with best available therapy for myelofibrosis. Blood. 2013 [cited 2017 Dec 27];122:4047-4053. Available from: http://www.ncbi.n/m.nih.gov/pubmed/24174625.

36. Verstovsek S, Mesa RA, Gotlib J, Gupta V, DiPersio JF, Catalano JV, et al. Long-term treatment with ruxolitinib for patients with myelofibrosis: 5-year update from the randomized, double-blind, placebo-controlled, phase 3 COMFORT-I trial. J Hematol Oncol Journal of Hematology \& Oncology. 2017; 10:1-14.

37. Harrison CN, Vannucchi AM, Kiladjian JJ, Al-Ali HK, Gisslinger H, Knoops L, et al. Long-term findings from COMFORT-II, a phase 3 study of ruxolitinib vs best available therapy for myelofibrosis. Leukemia. Nat Publ Group. 2016;30:1701-7. Available from: https://doi.org/10.1038/leu.2016.148.

38. Passamonti F, Griesshammer M, Palandri F, Egyed M, Benevolo G, Devos T, et al. Ruxolitinib for the treatment of inadequately controlled polycythaemia vera without splenomegaly (RESPONSE-2): a randomised, open-label, phase 3b study. Lancet. Oncol. Elsevier; 2017 [cited 2018 Jan 3];18:88-99. Available from: http://www.ncbi.nlm.nih.gov/pubmed/27916398.

39. Vannucchi AM. From leeches to personalized medicine: evolving concepts in the management of polycythemia vera. Haematologica. Haematologica; 2017 [cited 2018 Jan 19]:102:18-29. Available from: http://www.ncbi.nlm.nih. gov/pubmed/27884974.

40. Vannucchi AM, Kiladjian JJ, Griesshammer M, Masszi T, Durrant S, Passamonti F, et al. Ruxolitinib versus Standard Therapy for the Treatment of Polycythemia Vera. N. Engl. J. Med. Massachusetts Medical Society; 2015 [cited 2018 Jan 3];372:426-435. Available from: http://www.nejm.org/doi/10. 1056/NEJMoa1409002

41. Deininger M, Radich J, Burn TC, Huber R, Paranagama D, Verstovsek S. The effect of long-term ruxolitinib treatment on JAK2p.V617F allele burden in patients with myelofibrosis. Blood. American Society of Hematology; 2015 [cited 2018 Jan 2];126:1551-1554. Available from: http://www.ncbi.nlm.nih. gov/pubmed/26228487.

42. Harrison CN, Mead AJ, Panchal A, Fox S, Yap C, Gbandi E, et al. Ruxolitinib vs best available therapy for ET intolerant or resistant to hydroxycarbamide. Blood. 2017 [cited 2018 Jan 23];130:1889-1897. Available from: http://www. bloodjournal.org/lookup/doi/10.1182/blood-2017-05-785790.

43. Finazzi G. Ruxolitinib in ET: not all MPN are equal. Blood. American Society of Hematology; 2017 [cited 2018 Jan 23];130:1873-1874. Available from: http://www.ncbi.nlm.nih.gov/pubmed/29074591.

44. Verstovsek S, Passamonti F, Rambaldi A, Barosi G, Rumi E, Gattoni E, et al. Ruxolitinib for essential thrombocythemia refractory to or intolerant of hydroxyurea: long-term phase 2 study results. Blood. 2017 [cited 2018 Jan 23];130:1768-1771. Available from: http://www.bloodjournal.org/lookup/doi/ 10.1182/blood-2017-02-765032

45. Cardoso BA, Belo H, Barata JT, Almeida AM. The Bone Marrow-Mediated Protection of Myeloproliferative Neoplastic Cells to Vorinostat and Ruxolitinib Relies on the Activation of JNK and PI3K Signalling Pathways. PLoS One. 2015 [cited 2018 Jan 2];10:e0143897. Available from: http://journals.plos.org/plosone/ article?id=10.1371/journal.pone.0143897.

46. Bogani C, Bartalucci N, Martinelli S, Tozzi L, Guglielmelli P, Bosi A, et al. mTOR Inhibitors Alone and in Combination with JAK2 Inhibitors Effectively Inhibit Cells of Myeloproliferative Neoplasms on behalf of the Associazione Italiana per la Ricerca sul Cancro AGIMM Gruppo Italiano Malattie Mieloproliferative. 2013 [cited 2018 Jan 2]; Available from: http://journals.plos. org/plosone/article?id=10.1371/journal.pone.0054826.

47. Bartalucci N, Tozzi L, Bogani C, Martinelli S, Rotunno G, Villeval J-L, et al. Cotargeting the PI3K/mTOR and JAK2 signalling pathways produces synergistic activity against myeloproliferative neoplasms. J Cell Mol Med. 2013 [cited 2018 Jan 2];17:1385-1396. Available from: http://doi.wiley.com/10.1111/ jcmm.12162.

48. Bartalucci N, Guglielmelli P, Vannucchi AM. Rationale for Targeting the PI3K Akt/mTOR Pathway in Myeloproliferative Neoplasms. Clin. Lymphoma Myeloma Leuk. 2013 [cited 2018 Jan 2];13:S307-S309. Available from: http:// www.ncbi.nlm.nih.gov/pubmed/24290217.

49. Pandey R, Kapur R. Targeting phosphatidylinositol-3-kinase pathway for the treatment of Philadelphia-negative myeloproliferative neoplasms. Mol. Cancer. 2015 [cited 2017 Sep 18];14:118. Available from: http://www.ncbi. nlm.nih.gov/pubmed/26062813.

50. Khan I, Huang Z, Wen Q, Stankiewicz M, Gilles L, Goldenson B, et al. AKT is therapeutic target in myeloproliferative neoplasms. Leukemia. 2013 [cited 2018 Jan 2];27:1882-1890. Available from: https://www.nature.com/articles/ leu2013167.

51. Chen E, Mullally A. How does JAK2V617F contribute to the pathogenesis of myeloproliferative neoplasms? Hematology. 2014 [cited 2018 Jan 2];2014: 268-276. Available from: http://www.ncbi.nlm.nih.gov/pubmed/25696866.

52. Yan D, Hutchison RE, Mohi G. Critical requirement for Stat5 in a mouse model of polycythemia vera. Blood. 2012 [cited 2018 Jan 2];119:3539-49. Available from: http://www.ncbi.nlm.nih.gov/pubmed/22144185.

53. Berger A, SexI V, Valent P, Moriggl R. Inhibition of STAT5: A therapeutic option in BCR-ABL1-driven leukemia. Oncotarget. 2014 [cited 2018 Jan 22];5: 9564-9576. Available from: http://www.ncbi.nlm.nih.gov/pubmed/25333255.

54. Bartalucci N, Calabresi L, Balliu M, Martinelli S, Rossi M, et al. Inhibitors of the PI3K/mTOR pathway prevent STAT5 phosphorylation in JAK2V617F mutated cells through PP2A/CIP2A axis. Oncotarget. 2017;8(57). p. 96710-6724. Available from: https://www.ncbi.nlm.nih.gov/pubmed/29228564.

55. Klampfl T, Gisslinger $H$, Harutyunyan AS, Nivarthi H, Rumi E, Milosevic JD, et al. Somatic Mutations of Calreticulin in Myeloproliferative Neoplasms. N. Engl. J. Med. Massachusetts Medical Society; 2013 [cited 2018 Jan 2];369: 2379-2390. Available from: http://www.nejm.org/doi/10.1056/ NEJMoa1311347.

56. Nangalia J, Massie CE, Baxter EJ, Nice FL, Gundem G, Wedge DC, et al. Somatic CALR Mutations in Myeloproliferative Neoplasms with Nonmutated JAK2. N. Engl. J. Med. 2013 [cited 2018 Jan 2];369:2391-2405. Available from: http://www.ncbi.n/m.nih.gov/pubmed/24325359.

57. Michalak M, Groenendyk J, Szabo E, Gold LI, Opas M. Calreticulin, a multiprocess calcium-buffering chaperone of the endoplasmic reticulum. Biochem. J. Portland Press Limited; 2009 [cited 2018 Jan 19];417:651-666. Available from: http://www.ncbi.nlm.nih.gov/pubmed/19133842.

58. Pikman $Y$, Lee BH, Mercher T, McDowell E, Ebert BL, Gozo M, et al. MPLW515L is a novel somatic activating mutation in myelofibrosis with myeloid metaplasia. Sawyers C, editor. PLoS Med. 2006 [cited 2017 Sep 13]; 3:e270. Available from: http://dx.plos.org/10.1371/journal.pmed.0030270

59. Metcalf $D$. The granulocyte-macrophage colony-stimulating factors. Science 1985 [cited 2017 Apr 10];229:16-22. Available from: http://www.ncbi.nlm.nih gov/pubmed/2990035.

60. Beekman R, Touw IP. G-CSF and its receptor in myeloid malignancy. Blood. 2010 [cited 2017 Apr 10];115:5131-5136. Available from: http://www.ncbi. nlm.nih.gov/pubmed/20237318.

61. Liu F, Wu HY, Wesselschmidt R, Kornaga T, Link DC. Impaired production and increased apoptosis of neutrophils in granulocyte colony-stimulating factor receptor-deficient mice. Immunity. 1996 [cited 2017 Apr 10];5:491501. Available from: http://www.ncbi.nlm.nih.gov/pubmed/8934575. 
62. Maxson JE, Gotlib J, Pollyea D a, Fleischman AG, Agarwal A, Eide C a, et al. Oncogenic CSF3R mutations in chronic neutrophilic leukemia and atypical CML. N. Engl. J. Med. 2013;368:1781-1790. Available from: http://www.nejm. org/doi/full/10.1056/NEJMoa1214514

63. Hermans MH, Ward AC, Antonissen C, Karis A, Löwenberg B, Touw IP. Perturbed granulopoiesis in mice with a targeted mutation in the granulocyte colony-stimulating factor receptor gene associated with severe chronic neutropenia. Blood. 1998 [cited 2017 Apr 10];92:32-39. Available from: http://www.ncbi.nlm.nih.gov/pubmed/9639496.

64. Mitsui T, Watanabe S, Taniguchi Y, Hanada S, Ebihara Y, Sato T, et al. Impaired neutrophil maturation in truncated murine G-CSF receptortransgenic mice. Blood. 2003 [cited 2017 Apr 10];101:2990-2105. Available from: http://www.ncbi.n/m.nih.gov/pubmed/12672695.

65. Tian S, Lamb P, Seidel H, Stein R, Rosen J. Rapid activation of the STAT3 transcription factor by granulocyte colony-stimulating factor. Blood. 1994 [cited 2017 Apr 26];84:1760-1764. Available from: http://www.bloodjournal. org/content/84/6/1760.

66. Nicholson SE, Oates AC, Harpur AG, Ziemiecki A, Wilks AF, Layton JE. Tyrosine kinase JAK1 is associated with the granulocyte-colony-stimulating factor receptor and both become tyrosine-phosphorylated after receptor activation. Proc. Natl. Acad. Sci. U. S. A. 1994 [cited 2017 Apr 26];91:29852988. Available from: http://www.ncbi.nlm.nih.gov/pubmed/7512720.

67. Corey SJ, Burkhardt AL, Bolen JB, Geahlen RL, Tkatch LS, Tweardy DJ. Granulocyte colony-stimulating factor receptor signaling involves the formation of a three-component complex with Lyn and Syk protein-tyrosine kinases. Proc. Natl. Acad. Sci. U. S. A. 1994 [cited 2017 Apr 26];91:4683-4687. Available from: http://www.ncbi.nlm.nih.gov/pubmed/8197119.

68. Corey SJ, Dombrosky-Ferlan PM, Zuo S, Krohn E, Donnenberg AD, Zorich P, et al. Requirement of Src kinase Lyn for induction of DNA synthesis by granulocyte colony-stimulating factor. J. Biol. Chem. 1998 [cited 2017 Apr 26]; 273:3230-3235. Available from: http://www.ncbi.nlm.nih.gov/pubmed/9452436.

69. Pardanani a, Lasho TL, Laborde RR, Elliott M, Hanson C a, Knudson R a, et al. CSF3R T618I is a highly prevalent and specific mutation in chronic neutrophilic leukemia. Leukemia. Nature Publishing Group; 2013;27:18701873. Available from: http://www.ncbi.nlm.nih.gov/pubmed/23604229.

70. Meggendorfer M, Haferlach T, Alpermann T, Jeromin S, Haferlach C, Kern W, et al. Specific molecular mutation patterns delineate chronic neutrophilic leukemia, atypical chronic myeloid leukemia, and chronic myelomonocytic leukemia. Haematologica. 2014;99:e244-6.

71. Fleischman AG, Maxson JE, Luty SB, Agarwal A, Royer LR, Abel ML, et al. The CSF3R T618I mutation causes a lethal neutrophilic neoplasia in mice that is responsive to therapeutic JAK inhibition. Blood. 2013;122:3628-31.

72. Bartels S, Lehmann U, Büsche G, Schlue J, Hussein K, Debatin D, et al. De novo CSF3R mutation associated with transformation of myeloproliferative neoplasm to atypical CML. Ann Hematol. 2015;94:1255-6.

73. Maxson JE, Luty SB, MacManiman JD, Paik JC, Gotlib J, Greenberg P, et al. The colony-stimulating factor 3 receptor T640N mutation is oncogenic, sensitive toJAKInhibition, and mimics T618i. Clin Cancer Res. 2016;22:757-64.

74. Dao K-HT, Solti MB, Maxson JE, Winton EF, Press RD, Druker BJ, et al. Significant clinical response to JAK1/2 inhibition in a patient with CSF3RT6181-positive atypical chronic myeloid leukemia. Leuk. Res. reports. Elsevier; 2014 [cited 2017 Apr 27];3:67-69. Available from: http://www.ncbi.nlm.nih. gov/pubmed/25180155.

75. Freedman JL, Desai A V., Bailey LC, Aplenc R, Burnworth B, Zehentner BK, et al. Atypical Chronic Myeloid Leukemia in Two Pediatric Patients. Pediatr. Blood Cancer. 2016 [cited 2017 Apr 27];63:156-159. Available from: http:// www.ncbi.nlm.nih.gov/pubmed/26274939.

76. Zhang F, Cheong JK. The renewed battle against RAS-mutant cancers. Cell. Mol. Life Sci. Springer International Publishing; 2016;73:1845-1858.

77. Stephen AG, Esposito D, Bagni RG, McCormick F. Dragging ras back in the ring. Cancer Cell. Elsevier Inc.; 2014;25:272-281. Available from: https://doi. org/10.1016/j.ccr.2014.02.017.

78. Bowen DT, Frew ME, Hills R, Gale RE, Wheatley K, Groves MJ, et al. RAS mutation in acute myeloid leukemia is associated with distinct cytogenetic subgroups but does not influence outcome in patients younger than 60 years. Blood. 2005 [cited 2017 may 10];106:2113-2119. Available from: http://www.ncbi.nlm.nih.gov/pubmed/15951308.

79. Auewarakul CU, Lauhakirti D, Tocharoentanaphol C. Frequency of RAS gene mutation and its cooperative genetic events in Southeast Asian adult acute myeloid leukemia. Eur. J. Haematol. 2006 [cited 2017 may 10];77:51-56. Available from: http://www.ncbi.nlm.nih.gov/pubmed/16573741.
80. Kohlmann A, Grossmann V, Klein H-U, Schindela S, Weiss T, Kazak B, et al. Next-Generation Sequencing Technology Reveals a Characteristic Pattern of Molecular Mutations in $72.8 \%$ of Chronic Myelomonocytic Leukemia by Detecting Frequent Alterations in TET2, CBL, RAS, and RUNX1. J. Clin. Oncol. 2010 [cited 2017 may 11];28:3858-3865. Available from: http://www.ncbi. nlm.nih.gov/pubmed/20644105.

81. Miyauchi J, Asada M, Sasaki M, Tsunematsu Y, Kojima S, Mizutani S. Mutations of the N-ras gene in juvenile chronic myelogenous leukemia. Blood. 1994 [cited 2017 May 10];83:2248-2254. Available from: http://www. bloodjournal.org/content/83/8/2248.

82. Lito $\mathrm{P}$, Rosen $\mathrm{N}$, Solit DB. Tumor adaptation and resistance to RAF inhibitors. Nat. Med. Nature Publishing Group; 2013 [cited 2018 Jan 10];19:1401-1409. Available from: http://www.nature.com/doifinder/10.1038/nm.3392.

83. Karoulia Z, Gavathiotis E, Poulikakos PI. New perspectives for targeting RAF kinase in human cancer. Nat. Rev. Cancer. 2017 [cited 2018 Jan 19];17:676-691. Available from: http://www.ncbi.nlm.nih.gov/pubmed/ 28984291.

84. Heidorn SJ, Milagre C, Whittaker S, Nourry A, Niculescu-Duvas I, Dhomen N, et al. Kinase-Dead BRAF and Oncogenic RAS Cooperate to Drive Tumor Progression through CRAF. Cell. 2010 [cited 2018 Jan 11];140:209-221. Available from: http://www.ncbi.nlm.nih.gov/pubmed/20141835.

85. Hatzivassiliou G, Song K, Yen I, Brandhuber BJ, Anderson DJ, Alvarado R, et al. RAF inhibitors prime wild-type RAF to activate the MAPK pathway and enhance growth. Nature. Nature Publishing Group; 2010 [cited 2018 Jan 11]; 464:431-435. Available from: http://www.nature.com/doifinder/10.1038/ nature08833.

86. Holderfield M, Merritt H, Chan J, Wallroth M, Tandeske L, Zhai H, et al. RAF Inhibitors Activate the MAPK Pathway by Relieving Inhibitory Autophosphorylation. Cancer Cell. Cell Press; 2013 [cited 2018 Jan 10];23: 594-602. Available from: https://www.sciencedirect.com/science/article/pii/ S1535610813001347.

87. Van Meter MEM, Díaz-Flores E, Archard JA, Passegué E, Irish JM, Kotecha N, et al. K-RasG12D expression induces hyperproliferation and aberrant signaling in primary hematopoietic stem/progenitor cells. Blood. 2007 [cited 2017 May 10];109:3945-3952. Available from: http://www.bloodjournal.org/ content/109/9/3945.

88. Lyubynska N, Gorman MF, Lauchle JO, Hong WX, Akutagawa JK, Shannon K, et al. A MEK inhibitor abrogates myeloproliferative disease in Kras mutant mice. Sci Transl med. 2011;3:76ra27. Available from: http://www.ncbi.nIm.nih. gov/pubmed/21451123.

89. Burgess MR, Hwang E, Firestone AJ, Huang T, Xu J, Zuber J, et al. Preclinical ef fi cacy of MEK inhibition in Nras -mutant AML. Blood. 2014;124:3947-55

90. Brown AP, Carlson TCG, Loi C-M, Graziano MJ. Pharmacodynamic and toxicokinetic evaluation of the novel MEK inhibitor, PD0325901, in the rat following oral and intravenous administration. Cancer Chemother. Pharmacol. 2007 [cited 2017 May 12];59:671-679. Available from: http://link. springer.com/10.1007/s00280-006-0323-5.

91. Flaherty KT, Robert C, Hersey P, Nathan P, Garbe C, Milhem M, et al. Improved Survival with MEK Inhibition in BRAF-Mutated Melanoma. N. Engl. J. Med. 2012 [cited 2017 may 12];367:107-114. Available from: http://www. ncbi.nlm.nih.gov/pubmed/22663011.

92. Borthakur G, Popplewell L, Boyiadzis M, Foran J, Platzbecker U, Vey N, et al. Activity of the oral mitogen-activated protein kinase kinase inhibitor trametinib in RAS-mutant relapsed or refractory myeloid malignancies. Cancer. 2016;122:1871-9.

93. Khanna V, Pierce ST, Dao K-HT, Tognon CE, Hunt DE, Junio B, et al. Durable Disease Control with MEK Inhibition in a Patient with NRAS-mutated Atypical Chronic Myeloid Leukemia. Curēus. 2015;7:e414. Available from: https://www.ncbi.nlm.nih.gov/pubmed/26870618.

94. Britten CD. PI3K and MEK inhibitor combinations: examining the evidence in selected tumor types. Cancer Chemother. Pharmacol. 2013 [cited 2018 Jan 11];71:1395-1409. Available from: http://link.springer.com/10.1007/s00280013-2121-1.

95. Akutagawa J, Huang TQ, Epstein I, Chang T, Quirindongo-Crespo M, Cottonham CL, et al. Targeting the PI3K/Akt pathway in murine MDS/MPN driven by hyperactive Ras. Leukemia. 2016 [cited 2018 Jan 11];30:1335-1343. Available from: http://www.nature.com/articles/leu201614.

96. Riento K, Ridley AJ. Rocks: multifunctional kinases in cell behaviour. Nat. Rev. Mol. Cell Biol. Nature Publishing Group; 2003 [cited 2017 May 17];4:446-456. Available from: http://www.nature.com/doifinder/10.1038/nrm1128. 
97. Coleman ML, Sahai EA, Yeo M, Bosch M, Dewar A, Olson MF. Membrane blebbing during apoptosis results from caspase-mediated activation of ROCK I. Nat. Cell Biol. 2001 [cited 2017 may 17];3:339-345. Available from: http://www.ncbi.nlm.nih.gov/pubmed/11283606

98. Sebbagh M, Renvoizé C, Hamelin J, Riché N, Bertoglio J, Bréard J. Caspase-3mediated cleavage of ROCK I induces MLC phosphorylation and apoptotic membrane blebbing. Nat. Cell Biol. 2001 [cited 2017 may 17];3:346-352. Available from: http://www.ncbi.nlm.nih.gov/pubmed/11283607.

99. Sebbagh M, Hamelin J, Bertoglio J, Solary E, Bréard J. Direct cleavage of ROCK II by granzyme B induces target cell membrane blebbing in a caspase-independent manner. J. Exp. Med. 2005 [cited 2017 may 17];201: 465-471. Available from: http://www.ncbi.nlm.nih.gov/pubmed/15699075.

100. Fusella F, Ferretti R, Recupero D, Rocca S, Di Savino A, Tornillo G, et al. Morgana acts as a proto-oncogene through inhibition of a ROCK-PTEN pathway. J Pathol. 2014;234:152-63.

101. Mali RS, Ramdas B, Ma P, Shi J, Munugalavadla V, Sims E, et al. Rho kinase regulates the survival and transformation of cells bearing oncogenic forms of KIT, FLT3, and BCR-ABL. Cancer Cell. Elsevier Inc:; 2011;20:357-369. Available from: https://doi.org/10.1016/j.ccr.2011.07.016.

102. Wermke M, Camgoz A, Paszkowski-Rogacz M, Thieme S, von Bonin M, Dahl A, et al. RNAi profiling of primary human AML cells identifies ROCK1 as a therapeutic target and nominates fasudil as an antileukemic drug. Blood. 2015 [cited 2017 May 17];125:3760-3768. Available from: http://www. bloodjournal.org/cgi/doi/10.1182/blood-2014-07-590646.

103. Zhang C, Wang H-J, Bao Q-C, Wang L, Guo T-K, Chen W-L, et al. NRF2 promotes breast cancer cell proliferation and metastasis by increasing RhoA/ROCK pathway signal transduction. Oncotarget. 2016 [cited 2017 may 17];7:73593-73606. Available from: http://www.ncbi.nlm.nih.gov/pubmed/ 27713154

104. Li N, Tang A, Huang S, Li Z, Li X, Shen S, et al. MiR-126 suppresses colon cancer cell proliferation and invasion via inhibiting RhoA/ROCK signaling pathway. Mol. Cell. Biochem. 2013 [cited 2017 May 17];380:107-119. Available from: http://link.springer.com/10.1007/s11010-013-1664-0.

105. Leve F, Peres-Moreira RJ, Binato R, Abdelhay E, Morgado-Díaz JA. LPA Induces Colon Cancer Cell Proliferation through a Cooperation between the ROCK and STAT-3 Pathways. Anant S, editor. PLoS One. 2015 [cited 2017 May 17];10: e0139094. Available from: http://dx.plos.org/10.1371/journal.pone.0139094.

106. Burthem J, Rees-Unwin K, Mottram R, Adams J, Lucas GS, Spooncer E, et al. The $\rho$-kinase inhibitors $Y$-27632 and fasudil act synergistically with imatinib to inhibit the expansion of ex vivo CD34+ CML progenitor cells. Leukemia. 2007 [cited 2017 may 17];21:1708-1714. Available from: http://www.ncbi. nlm.nih.gov/pubmed/17554385.

107. Mali RS, Kapur S, Kapur R. Role of Rho kinases in abnormal and normal hematopoiesis. Curr. Opin. Hematol. 2014 [cited 2017 may 17];21:271-275. Available from: http://www.ncbi.nlm.nih.gov/pubmed/24867289.

108. Wermke M, Camgoz A, Paszkowski-Rogacz M, Thieme S, Von Bonin M, Dahl A, et al. RNAi profiling of primary human AML cells identifies ROCK1 as a therapeutic target and nominates fasudil as an antileukemic drug. Blood. 2015;125:3760-8.

109. Brancaccio M, Menini N, Bongioanni D, Ferretti R, De Acetis M, Silengo L, et al. Chp-1 and melusin, two CHORD containing proteins in vertebrates. FEBS Lett. 2003 [cited 2017 Sep 13];551:47-52. Available from: http://www.ncbi. nlm.nih.gov/pubmed/12965203.

110. Ferretti R, Palumbo V, Di Savino A, Velasco S, Sbroggiò M, Sportoletti P, et al. Morgana/chp-1, a ROCK inhibitor involved in centrosome duplication and tumorigenesis. Dev. Cell. Elsevier Ltd; 2010;18:486-495. Available from: https://doi.org/10.1016/j.devcel.2009.12.020

111. Brancaccio M, Rocca S, Secli L, Busso E, Fusella F. The double face of Morgana in tumorigenesis. Oncotarget. 2015 [cited 2017 Sep 13];6:4260342612. Available from: http://www.oncotarget.com/fulltext/6058.

112. Di Savino A, Panuzzo C, Rocca S, Familiari U, Piazza R, Crivellaro S, et al. Morgana acts as an oncosuppressor in chronic myeloid leukemia. Blood. 2015 [cited 2017 Feb 21];125:2245-2253. Available from: http://www. bloodjournal.org/cgi/doi/10.1182/blood-2014-05-575001.

113. Fusella F, Secli L, Busso E, Krepelova A, Moiso E, Rocca S, et al. The IKK/NF$\mathrm{KB}$ signaling pathway requires Morgana to drive breast cancer metastasis. Nat. Commun. 2017 [cited 2018 Jan 19];8:1636. Available from: http://www. ncbi.nlm.nih.gov/pubmed/29158506.

114. Meyer SC, Levine RL. Molecular pathways: molecular basis for sensitivity and resistance to JAK kinase inhibitors. Clin. Cancer Res. 2014 [cited 2017 Sep 18]; 20:2051-2059. Available from: http://www.ncbi.nlm.nih.gov/pubmed/24583800.
115. Meggendorfer M, Bacher U, Alpermann T, Haferlach C, Kern W, GambacortiPasserini $C$, et al. SETBP1 mutations occur in $9 \%$ of MDS/MPN and in $4 \%$ of MPN cases and are strongly associated with atypical CML, monosomy 7 , isochromosome i(17)(q10), ASXL1 and CBL mutations. Leukemia. 2013 [cited 2017 Feb 22];27:1852-1860. Available from: http://www.ncbi.nlm.nih.gov/ pubmed/23628959.

116. Gambacorti-Passerini CB, Donadoni C, Parmiani A, Pirola A, Redaelli S, Signore $\mathrm{G}$, et al. Recurrent ETNK1 mutations in atypical chronic myeloid leukemia. Blood. 2015;125:499-503.

117. Piazza R, Valletta S, Winkelmann N, Redaelli S, Spinelli R, Pirola A, et al. Recurrent SETBP1 mutations in atypical chronic myeloid leukemia. Nat. Genet. Nature Research; 2012 [cited 2017 Feb 22];45:18-24. Available from: http://www.nature.com/doifinder/10.1038/ng.2495.

118. Spinelli R, Pirola A, Redaelli S, Sharma N, Raman H, Valletta S, et al. Identification of novel point mutations in splicing sites integrating wholeexome and RNA-seq data in myeloproliferative diseases. Mol. Genet. genomic Med. Wiley-Blackwell; 2013 [cited 2017 mar 6];1:246-259. Available from: http://www.ncbi.nlm.nih.gov/pubmed/24498620.

119. Makishima H, Yoshida K, Nguyen N, Przychodzen B, Sanada M, Okuno Y, et al. Somatic SETBP1 mutations in myeloid malignancies. Nat. Genet. Nature Research; 2013 [cited 2017 Mar 6];45:942-946. Available from: http://www. nature.com/doifinder/10.1038/ng.2696.

120. Fend F, Horn T, Koch I, Vela T, Orazi A. Atypical chronic myeloid leukemia as defined in the WHO classification is a JAK2 V617F negative neoplasm. Leuk Res. 2008;32:1931-5.

121. Steensma DP, Dewald GW, Lasho TL, Powell HL, McClure RF, Levine RL, et al. The JAK2 V617F activating tyrosine kinase mutation is an infrequent event in both 'atypical' myeloproliferative disorders and myelodysplastic syndromes. Blood. 2005;106:1207-9.

122. Abdel-Wahab O, Mullally A, Hedvat C, Garcia-Manero G, Patel J, Wadleigh M, et al. Genetic characterization of TET1, TET2, and TET3 alterations in myeloid malignancies. Blood. 2009 [cited 2017 Jun 13];114:144-147. Available from: http://www.ncbi.nlm.nih.gov/pubmed/19420352.

123. Patnaik MM, Barraco D, Lasho TL, Finke CM, Reichard K, Hoversten KP, et al. Targeted next generation sequencing and identification of risk factors in World Health Organization defined atypical chronic myeloid leukemia. Am. J. Hematol. 2017 [cited 2017 Jun 13];92:542-548. Available from: http:// www.ncbi.n/m.nih.gov/pubmed/28314085.

124. Acuna-Hidalgo R, Deriziotis P, Steehouwer M, Gilissen C, Graham SA, van Dam $S$, et al. Overlapping SETBP1 gain-of-function mutations in SchinzelGiedion syndrome and hematologic malignancies. Barsh GS, editor. PLoS Genet. 2017 [cited 2017 Sep 13];13:e1006683. Available from: http://dx.plos. org/10.1371/journal.pgen.1006683.

125. Switzer CH, Cheng RYS, Vitek TM, Christensen DJ, Wink DA, Vitek MP. Targeting SET/I(2)PP2A oncoprotein functions as a multi-pathway strategy for cancer therapy. Oncogene. 2011 [cited 2017 Jun 14];30:2504-2513. Available from: http://www.nature.com/doifinder/10.1038/onc.2010.622.

126. Cristóbal I, Blanco FJ, Garcia-Orti L, Marcotegui N, Vicente C, Rifon J, et al. SETBP1 overexpression is a novel leukemogenic mechanism that predicts adverse outcome in elderly patients with acute myeloid leukemia. Blood. 2010 [cited 2017 May 18];115:615-625. Available from: http://www. bloodjournal.org/content/115/3/615.

127. Cristóbal I, Garcia-Orti L, Cirauqui C, Alonso MM, Calasanz MJ, Odero MD. PP2A impaired activity is a common event in acute myeloid leukemia and its activation by forskolin has a potent anti-leukemic effect. Leukemia. Nature Publishing Group; 2011 [cited 2017 Mar 6];25:606-614. Available from: http://www.nature.com/doifinder/10.1038/leu.2010.294.

128. Tartaglia M, Niemeyer CM, Fragale A, Song X, Buechner J, Jung A, et al. Somatic mutations in PTPN11 in juvenile myelomonocytic leukemia, myelodysplastic syndromes and acute myeloid leukemia. Nat. Genet. 2003 [cited 2017 Jun 14];34:148-150. Available from: http://www.ncbi.nlm.nih. gov/pubmed/12717436.

129. Yin T, Shen R, Feng GS, Yang YC. Molecular characterization of specific interactions between SHP-2 phosphatase and JAK tyrosine kinases. J. Biol. Chem. American Society for Biochemistry and Molecular Biology; 1997 [cited 2018 Jan 15];272:1032-1037. Available from: http://www.ncbi.nlm.nih. gov/pubmed/8995399.

130. Chen C-Y, Lin L-I, Tang J-L, Tsay W, Chang H-H, Yeh Y-C, et al. Acquisition of JAK2, PTPN11 and RAS mutations during disease progression in primary myelodysplastic syndrome. Leukemia. Nature Publishing Group; 2006 [cited 2018 Jan 15];20:1155-1158. Available from: http://www.nature.com/articles/2404190. 
131. Lasho TL, Finke CM, Zblewski D, Patnaik M, Ketterling RP, Chen D, et al. Novel recurrent mutations in ethanolamine kinase 1 (ETNK1) gene in systemic mastocytosis with eosinophilia and chronic myelomonocytic leukemia. Blood Cancer J. Nat Publ Group; 2015;5:e275. Available from: http://www.nature.com/doifinder/10.1038/bcj.2014.94.

132. Kosmider O. Mutations of ETNK1 in aCML and CMML. Blood. 2015 [cited 2017 Jun 27];125:422-423. Available from: http://www.bloodjournal.org/ content/125/3/422.

133. Calzada E, Onguka O, Claypool SM. Phosphatidylethanolamine Metabolism in Health and Disease. Int Rev Cell Mol Biol. 2016;321:29-88. Available from: https://www.sciencedirect.com/science/article/pii/S1937644815000970.

134. Sood R, Kamikubo Y, Liu P. Role of RUNX1 in hematological malignancies. Blood. 2017;129:blood-2016-10-687830. Available from: http://www. bloodjournal.org/lookup/doi/10.1182/blood-2016-10-687830.

135. Bellissimo DC, Speck NA. RUNX1 Mutations in Inherited and Sporadic Leukemia. Front. cell Dev. Biol. 2017 [cited 2018 Jan 22];5:111. Available from: http://journal.frontiersin.org/article/10.3389/fcell.2017.00111/full.

136. Tahiliani M, Koh KP, Shen Y, Pastor WA, Bandukwala H, Brudno Y, et al. Conversion of 5-methylcytosine to 5-hydroxymethylcytosine in mammalian DNA by MLL partner TET1. Science. 2009 [cited 2017 Jun 13];324:930-935. Available from: http://www.sciencemag.org/cgi/doi/10.1126/science. 1170116.

137. He Y-F, Li B-Z, Li Z, Liu P, Wang Y, Tang Q, et al. Tet-Mediated Formation of 5-Carboxylcytosine and Its Excision by TDG in Mammalian DNA. Science (80-. ). 2011 [cited 2017 Jun 13];333:1303-1307. Available from: http://www. ncbi.nlm.nih.gov/pubmed/21817016.

138. Rasmussen KD, Helin K. Role of TET enzymes in DNA methylation, development, and cancer. Genes Dev. 2016;30:733-50.

139. Delhommeau F, Dupont S, Della Valle V, James C, Trannoy S, Massé A, et al. Mutation in TET2 in myeloid cancers. N. Engl. J. Med. 2009 [cited 2017 Jun 13];360:2289-2301. Available from: http://www.nejm.org/doi/abs/10.1056/ NEJMoa0810069.

140. Jankowska AM, Szpurka H, Tiu R V., Makishima H, Afable M, Huh J, et al. Loss of heterozygosity $4 \mathrm{q} 24$ and TET2 mutations associated with myelodysplastic/myeloproliferative neoplasms. Blood. 2009 [cited 2017 Jun 13];113:6403-6410. Available from: http://www.bloodjournal.org/cgi/ doi/10.1182/blood-2009-02-205690

141. Kosmider O, Gelsi-Boyer V, Ciudad M, Racoeur C, Jooste V, Vey N, et al. TET2 gene mutation is a frequent and adverse event in chronic myelomonocytic leukemia. Haematologica. 2009 [cited 2017 Jun 13];94:1676-1681. Available from: http://www.haematologica.org/cgi/doi/10.3324/haematol.2009.011205.

142. Kosmider O, Gelsi-Boyer V, Cheok M, Grabar S, Della-Valle V, Picard F, et al. TET2 mutation is an independent favorable prognostic factor in myelodysplastic syndromes (MDSs). Blood. 2009 [cited 2017 Jun 13];114: 3285-3291. Available from: http://www.bloodjournal.org/cgi/doi/10.1182/ blood-2009-04-215814

143. Figueroa ME, Abdel-Wahab O, Lu C, Ward PS, Patel J, Shih A, et al. Leukemic IDH1 and IDH2 Mutations Result in a Hypermethylation Phenotype, Disrupt TET2 Function, and Impair Hematopoietic Differentiation. Cancer Cell. 2010 [cited 2017 Jun 13];18:553-567. Available from: http://www.ncbi.nlm.nih. gov/pubmed/21130701.

144. Jiang H, Wu Z, Ren LI, Tao D, Tong H. Decitabine for the treatment of atypical chronic myeloid leukemia: A report of two cases. Oncol. Lett. Spandidos Publications; 2016 [cited 2018 Jan 19];11:689-692. Available from: http://www.ncbi.nlm.nih.gov/pubmed/26870268.

145. Mao L, You L, Yang M, Li Y, Ye X, et a. The First Case of Decitabine Successfully in Treatment of Atypical Chronic Myeloid Leukemia with CEBPA Double Mutation. Chemotherapy. 2013 [cited 2018 Jan 19]; 2:114.

146. Hausmann H, Bhatt VR, Yuan J, Maness LJ, Ganti AK. Activity of single-agent decitabine in atypical chronic myeloid leukemia. J. Oncol. Pharm. Pract. 2016 [cited 2018 Jan 19];22:790-794. Available from: http://www.ncbi.nIm. nih.gov/pubmed/26378157.

147. Tong X, Li J, Zhou Z, Zheng D, Liu J, Su C. Efficacy and side-effects of decitabine in treatment of atypical chronic myeloid leukemia. Leuk. Lymphoma. 2015 [cited 2018 Jan 19];56:1911-Su 3. Available from: http:// www.ncbi.nlm.nih.gov/pubmed/25426665.

148. Abdel-Wahab O, Adli M, LaFave LM, Gao J, Hricik T, Shih AH, et al. ASXL1 Mutations Promote Myeloid Transformation through Loss of PRC2-Mediated Gene Repression. Cancer Cell. 2012 [cited 2017 Jun 13];22:180-193. Available from: http://www.ncbi.n/m.nih.gov/pubmed/22897849.
149. Kunimoto $H$, Nakajima $H$. Epigenetic dysregulation of hematopoietic stem cells and preleukemic state. Int. J. Hematol. 2017 [cited 2017 Jun 27];106:3444. Available from: http://www.ncbi.nlm.nih.gov/pubmed/28555413.

150. Jaiswal S, Fontanillas P, Flannick J, Manning A, Grauman P V., Mar BG, et al. Age-Related Clonal Hematopoiesis Associated with Adverse Outcomes. N. Engl. J. Med. Massachusetts Medical Society; 2014 [cited 2018 Jan 15];371: 2488-2498. Available from: http://www.nejm.org/doi/10.1056/ NEJMoa1408617.

151. Genovese G, Kähler AK, Handsaker RE, Lindberg J, Rose SA, Bakhoum SF, et al. Clonal hematopoiesis and blood-cancer risk inferred from blood DNA sequence. N. Engl. J. Med. 2014 [cited 2018 Jan 22];371:2477-2487. Available from: http://www.nejm.org/doi/10.1056/NEJMoa1409405.

\section{Submit your next manuscript to BioMed Central and we will help you at every step:}

- We accept pre-submission inquiries

- Our selector tool helps you to find the most relevant journal

- We provide round the clock customer support

- Convenient online submission

- Thorough peer review

- Inclusion in PubMed and all major indexing services

- Maximum visibility for your research

Submit your manuscript at www.biomedcentral.com/submit
) Biomed Central 